\title{
MACROECONOMIC FACTORS, CORRUPTION, NPAS IN 4 PUBLIC SECTOR BANKS: A CROSS STUDY
}

\author{
Sai Preethi Krishnaswamy ${ }^{1}$ \\ ${ }^{1}$ Symbiosis Institute of Business Management (SIBM), Symbiosis International (Deemed University) (SIU) \\ Electronic City, Hosur Road,Bengaluru, Karnataka, India
}

\begin{abstract}
Banks play a vital role in economic development and growth of a country. A sound and healthy financial institution ensures overall stability of the system. Commercial and cooperative banks together constitute the Indian Banking System. Commercial Banks account for more than $90 \%$ of the banking sector's assets. The public sector banks account for a substantial part of the banking activity in India. The growth in banking sector has been burdened and hindered by increasing non-performing assets. In this paper, we aim to understand the influence of macroeconomic factors such as GDP per capita, Real Interest rates and inflation along with some bank factors such as bank size, diversification of assets and priority sector lending on NPAs of four PSBs - Punjab National Bank, Andhra Bank, Corporation Bank and Indian Bank. This paper also aims to understand whether corruption could be a determinant for NPAs in these banks.
\end{abstract}

Keyword: Banking sector in India, non-performing assets, corruption, PSBs

\section{Introduction}

\subsection{Banking Sector \& PSBs in India}

Commercial and cooperative banks together constitute the financial framework in India of which the former represent around $90 \%$ of the banking framework's assets. The SCBs are classified based on structure of ownership as Public Sector Banks (PSBs), Private Banks under Indian ownership, and Foreign Banks operating in India.

The Indian banking system has grown phenomenally over the years. Most of this growth could be credited to PSBs. According to RBI, public sector banks amount to over $60 \%$ of the total assets of all SCBs in 2019. This elucidates the importance of PSBs and impact of NPAs on the entire banking system.

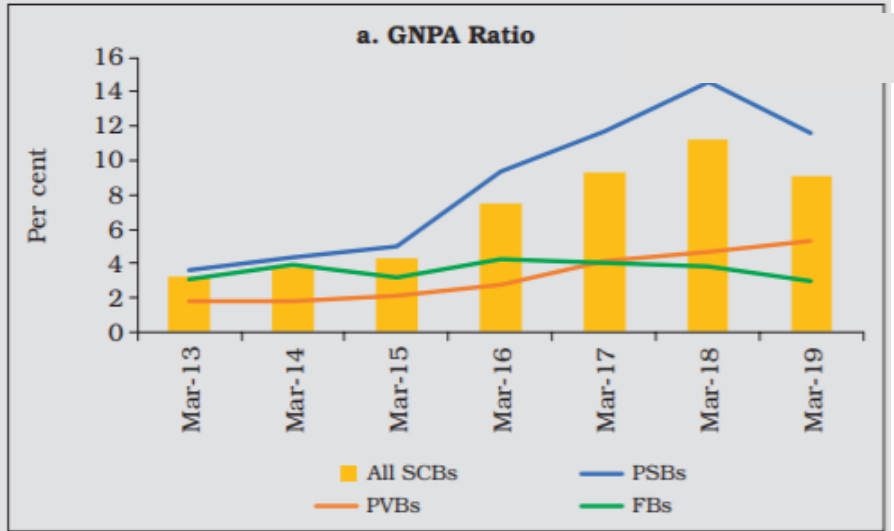

Figure 1: Gross NPAs in Indian Banking Sector Source: Report on Trend and Progress of Banking in India 2018-19, RBI website

PSBs are not in a good shape due to increasing NPAs, huge losses and decrease in credit growth. They have been facing an incredible competition from Private Banks. There has been a dearth of capital for PSBs which led to mergers and recapitalisation initiatives by $\mathrm{RBI}$ to strengthen the framework. There are 12 PSBs in India post mergers. The need of the hour is to understand how to reduce NPAs and maintain stability in the financial system.

\subsection{Determinants for NPAs}

The deterioration in asset quality of Indian banks, especially that of PSBs, could be tracked back to the credit explosion of 2006-2011 when bank credit increased at an average rate of more than $20 \%$. Unfavourable macro-financial environment; lenient credit evaluation and post-sanction monitoring benchmarks; project lags and the absence of a strong bankruptcy administration until May 2016.

The non-performing assets of the banking industry have been increasing over the years. According to RBI's Financial Stability Report of 2019, the Gross NPA ratio stood at $9.3 \%$ for all SCBs.

High NPAs affect the profitability of banks. They lead to capital erosion of banks. Banks face the risk of liquidity crunch if the NPAs increase beyond acceptable threshold. This may cause panic among the public who might have placed their earnings in the form of deposits in these banks. A sudden surge in bank runs could lead to a ripple effect that topples the whole system. 
To

understand how to reduce NPAs, we have to first identify factors that would lead to NPAs. Louzis, Vouldis, and Metaxas (2012) explained that bad loans are caused mainly due to macroeconomic factors such as GDP, unemployment and public borrowings and by quality of management.

Along with macroeconomic factors, we should also look at particular bank factors such as the PSB's lending policy, size of the bank, lending to priority sector and diversification of assets.

Literature suggests that banks that are larger in size have greater resources and manpower to dedicate time to the process of credit appraisal and due diligence. This means that larger the bank, smaller the number of NPAs. It is also implied that a larger bank has a better management.

Diversification of assets by banks is a way to reduce their risk by not keeping all their eggs in one basket but have many baskets and distribute the eggs accordingly. Public Sector Banks can allocate their capital in diverse assets to avoid a liquidity crunch in case any one large borrower defaults repayment.

Priority Sector Lending is lending to those sectors that need economic assistance and may not have access to adequate credit. The RBI stipulates that every bank should be lending to priority sectors like agricultute, MSMEs, low-income groups and weaker sections to ensure an all-round development of the country. This could sometimes lead to loan defaults and consequently, NPAs. We try to understand if this is a determinant for NPAs in the 4 PSBs.

Corruption could have a significant negative influence on economic growth. There has been little research done in exploring the impact of corruption on financial strength of a bank and on economic expansion. Corruption altering a bank's functioning can result from numerous causes: firms may bribe political figures (For example: to procure loans by sidestepping the loan evaluation procedures, to gain regulatory forbearance), etc.

While there is a high likelihood of a nation with a highly corrupt public sector having an extremely corrupt banking framework, corruption does not essentially lead to nonperforming loans in the banking sector. Even if a borrower with a bad project receives capital through corrupt means, it cannot be known if the project will succeed, though the likelihood of success would relatively be low.

\section{Purpose of Paper}

In this paper, we'll take a look at the various determinants of NPAs and their influence on four Public Sector Banks Punjab National Bank, Andhra Bank, Corporation Bank and Indian Bank.

The paper is aimed to do a cross study of macroeconomic factors like GDP per capita, inflation, Real Interest rates, and bank factors such as bank size, diversification and priority sector lending on non-performing assets on the forementioned public sector banks.

We will also explore the possibility of corruption as a factor for NPAs in the four PSBs.

\section{Literature Review}

2.1 PSBs and NPAs

(Kaur \& Sharma, 2011) analyzed the performance of 27 banks and ranked them based on key operational, financial and efficiency ratios. The top 4 banks according to their analysis were - Punjab National Bank, Andhra Bank, Corporation Bank and Indian Bank.

(Balikai \& Bannig, 2019) analyzed the financial resilience of 6 nationalized banks using CAMEL model for the period of 2008 to 2018. Using the CAMEL model, they arrived at a conclusion that Andhra Bank was performing the best.

(S, Dr. Rajamohan, 2012) provided a model for assessing NPAs in commercial banks. In our paper, we have chosen a few factors to check their influence on NPAs in PSBs.

\subsection{Macroeconomic Factors and Bank Factors}

(Laila, 2017) found out the factors influencing NPAs in the Banking System of India and how they vary in banks based on the structure of their ownership i.e., public sector banks, private banks and foreign banks from the period of 2005 to 2014. In our paper, we are going to further narrow down the scope to 4 PSBs from the period of 2010 to 2019.

The results from (Laila, 2017) show that macroeconomic factors like $\log$ of per capita GDP and inflation rate significantly affect non-performing loans in public sector banks. We have added another macroeconomic factor- real interest rate in our paper. Bank size and diversification have been proved to be significant for private banks.

(Kaur \& Kaur, 2015) evaluated the monetary performance of leading 5 PSBs for the period of 2009 to 2014 by using the CAMEL model including ratios for capital adequacy, management efficiency, asset quality, earning quality and liquidity.

\subsection{Corruption}

(Park, 2012) explored the effect of corruption on both banking system and economic expansion in various countries all over the world. The results of cross-sectional regression from the paper indicate that corruption severely affects nonperforming loans in the banking sector. Based on this premise, we have decided to apply and check if corruption affects bad loans in the 4 PSBs particularly in India.

(MSB Ali, Fhima Fredj, \& Ridha Nouira, 2020) assesses the consequence of corruption on the emergence of banking crisis in 38 nations around the world. They concluded that corruption surges the likelihood of banking crises. In bank sector lending, corruption has an undesirable influence.

\section{Methodology}


This is a descriptive and exploratory paper. In this paper, I've tried to understand the influence of macroeconomic factors and bank factors on NPAs in four PSBs- PNB, Andhra Bank, Corporation Bank and Indian Bank. We will also explore if corruption can be a factor for the same.

\subsection{Data Collection}

The study has been done for the period of 2010 to 2019. This paper is based on secondary data compiled from the official websites of RBI and the World Bank.

The macroeconomic factors such as Real GDP per capita, Inflation rates, Real interest rates have been taken from the World Bank website while the bank factors i.e., bank size
(BS), diversification (Div) and priority sector lending (PSL) have been calculated from the annual reports of PNB, Andhra Bank, Corporation Bank and Indian Bank for the period of 10 years. The data for bank factors for the entire banking sector has been taken from RBI website.

Transparency International publishes a corruption perception index (CPI) score for every country. The CPI score for India has been used as a proxy for corruption in India.

\subsection{Data Variables}

The dependent variable to determine NPAs in each of the four banks is take as a ratio of Net NPAs to Net Advances.

\begin{tabular}{|l|l|l|l|l|}
\hline Net NPA/ Net Advances & PNB & Andhra Bank & Corporation Bank & $\begin{array}{l}\text { Indian } \\
\text { Bank }\end{array}$ \\
\hline $\mathbf{2 0 1 0}$ & 0.85 & 0.38 & 0.46 & 0.53 \\
\hline $\mathbf{2 0 1 1}$ & 1.52 & 0.91 & 0.87 & 1.33 \\
\hline $\mathbf{2 0 1 2}$ & 2.35 & 2.45 & 1.19 & 2.26 \\
\hline $\mathbf{2 0 1 3}$ & 2.85 & 3.11 & 2.32 & 2.26 \\
\hline $\mathbf{2 0 1 4}$ & 4.06 & 2.93 & 3.08 & 2.5 \\
\hline $\mathbf{2 0 1 5}$ & 8.61 & 4.61 & 6.53 & 4.2 \\
\hline $\mathbf{2 0 1 6}$ & 7.81 & 7.57 & 8.33 & 4.39 \\
\hline $\mathbf{2 0 1 7}$ & 11.24 & 8.48 & 11.74 & 3.81 \\
\hline $\mathbf{2 0 1 8}$ & 6.56 & 5.73 & 5.71 & 3.75 \\
\hline $\mathbf{2 0 1 9}$ & 5.78 & 5.49 & 4.91 & \\
\hline
\end{tabular}

Table 1: Net NPAs to Net Advances for 4 PSBs.

Source: Annual Reports of PNB, Andhra Bank, Corporation Bank, Indian Bank

The macroeconomic factors considered in this paper are natural logarithm of Real GDP per Capita, Inflation and Real Interest Rates. Literature on this topic has not considered the interest rates in the past. Hence, I've tried to find its influence on NPAs in the 4 banks.

Transparency International publishes a Corruption Perception Index (CPI score) every year for different countries across the world. The CPI score has been used as a proxy for corruption in this paper. Just as suggested in (Park, 2012), the CPI score depicts the extent of corruption prevalent among officials and politicians. The higher the CPI score, lower is the level of corruption. Therefore, for ease of calculation, the following conversion has been made to arrive at the corruption index (CI).

\section{$\mathrm{CI}=\mathbf{1 0 0 - \mathrm { CPI }}$}

The bank factors used in this study have been adopted from (Laila, 2017) where bank size has been taken as a ratio of the bank to total assets of the entire banking system. Priority Sector Lending can be taken as a ratio of PSL of the bank to total lending of the banking system. Diversification can be depicted as a ratio of total loans of the bank to total loans of banking sector.

\begin{tabular}{|l|l|}
\hline Variable & Definition \\
\hline GDP & Natural Logarithm of Real GDP per capita \\
\hline
\end{tabular}




\begin{tabular}{|l|l|}
\hline Inflation (Infl) & Inflation Rate \\
\hline Interest Rates (Int) & Real Interest Rate \\
\hline Bank Size (BS) & $\frac{\text { Total assets of the bank }}{\text { Total assets of the banking sector }}$ \\
\hline Diversification (Div) & Total loans of the bank \\
\hline Priority Sector Lending (PSL) & $\frac{\text { Priority sector lending }}{\text { Total lending }}$ \\
\hline
\end{tabular}

\section{Table 2: Data Variables and their definition}

In this paper, the statistical tool used to determine the relationship between the dependent variable and its factors is linear regression.

\subsection{Objectives of Research}

To analyze the impact of GDP per capita, inflation rate, interest rate on NPAs in each of the 4 PSBs.
To understand the influence of bank size, diversification and priority sector lending on NPAs for the banks.

To determine if corruption can be considered as a determinant of NPAs in these 4 banks.

\section{Results and Discussion}

\subsection{Punjab National Bank}

\begin{tabular}{|c|c|c|c|c|c|c|c|}
\hline PNB & GDP & Infl & Intr & $\mathbf{C I}$ & BS & Div & PSL \\
\hline Significance & $0.0069^{*}$ & $0.0003^{*}$ & $0.015^{*}$ & $0.085 * *$ & $0.033^{*}$ & $0.013^{*}$ & $0.095 * *$ \\
\hline NPA Correlation & 0.79 & -0.91 & 0.73 & 0.53 & -0.67 & -0.75 & 0.56 \\
\hline & \multicolumn{7}{|c|}{$*$ significant at 0.05} \\
\hline & \multicolumn{7}{|c|}{$* *$ significant at 0.1} \\
\hline
\end{tabular}

\section{Table 3: Regression results for Punjab National Bank}

The results show that the NPAs in PNB are affected by macroeconomic factors, bank factors and corruption. GDP is significant at alpha $=0.05$ with a positive correlation. Inflation has a negative correlation which means that higher inflation, lower NPAs and Interest rates have a direct relationship with NPAs. The bank size of PNB also has a role to play in its NPAs. It has an inverse relationship which means larger the bank, lower the NPAs. The diversification of the bank has a negative correlation with the dependent variable showing that a bank that diversifies its assets can avoid the occurrence of NPAs. Priority Sector Lending and Corruption Index are significant at alpha $=0.1$. PSL has a positive correlation with NPAs showing that higher PSL, higher NPAs. Corruption too has a direct relation with NPAs for PNB.

4.2 Andhra Bank

\begin{tabular}{|l|l|l|l|l|l|l|l|}
\hline Andhra Bank & GDP & Infl & Intr & CI & BS & Div & PSL \\
\hline Significance & $0.001^{*}$ & $0.0014^{*}$ & $0.021^{*}$ & $0.268^{* * *}$ & $0.033^{*}$ & $0.638^{* * *}$ & $0.259^{* * *}$ \\
\hline NPA Correlation & 0.868 & -0.858 & 0.711 & 0.590 & -0.733 & 0.170 & 0.394 \\
\hline & $*$ significant at 0.05 \\
\hline
\end{tabular}

\section{Table 4: Regression results for Andhra Bank}

The results show that the NPAs in Andhra Bank are affected by macroeconomic 
factor $\mathrm{s}$ and bank size. GDP is significant at alpha $=0.05$ with a positive correlation. Inflation has a negative correlation which means that higher inflation, lower NPAs and Interest rates have a direct relationship with NPAs. The bank size of Andhra Bank also has a role to play in its NPAs. It has an inverse relationship which means larger the bank, lower the NPAs. The diversification of the bank has been proved to be insignificant to the dependent variable for this bank. Priority Sector Lending and Corruption Index are insignificant too, hence their correlation does not matter in this case.

4.3 Corporation Bank

\begin{tabular}{|l|l|l|l|l|l|l|l|}
\hline Corporation Bank & GDP & Infl & Intr & CI & BS & Div & PSL \\
\hline Significance & $0.011^{*}$ & $0.0004^{*}$ & $0.041^{*}$ & $0.135^{* * *}$ & $0.021^{*}$ & $0.011^{*}$ & $0.816^{* * *}$ \\
\hline NPA Correlation & 0.76 & -0.89 & 0.65 & 0.52 & -0.71 & -0.75 & 0.08 \\
\hline & $*$ significant at $\mathbf{0 . 0 5}$ \\
& \multicolumn{3}{|l|}{$* * *$ Not significant } \\
\hline
\end{tabular}

\section{Table 5: Regression results for Corporation Bank}

The results show that the NPAs in Corporation Bank are affected by macroeconomic factors, diversification and bank size. GDP is significant at alpha $=0.05$ with a positive correlation. Inflation has a negative correlation which means that higher inflation, lower NPAs and Interest rates have a direct relationship with NPAs. The bank size of Corporation Bank also has a role to play in its NPAs. It has an inverse 4.4 Indian Bank

\begin{tabular}{|l|l|l|l|l|l|l|l|}
\hline Indian Bank & GDP & Infl & Intr & CI & BS & Div & PSL \\
\hline Significance & $0.003 *$ & $0.002^{*}$ & $0.001^{*}$ & $0.093 * *$ & $0.0009 *$ & $0.74 * *$ & $0.831 * * *$ \\
\hline NPA Correlation & 0.83 & -0.84 & 0.85 & 0.58 & -0.87 & 0.12 & 0.08 \\
\hline & $*$ significant at 0.05 \\
\hline & $* *$ significant at 0.1 \\
\hline
\end{tabular}

\section{Table 6: Regression results for Indian Bank}

The results show that the NPAs in Indian Bank are affected by macroeconomic factors, bank size and corruption. GDP is significant at alpha $=0.05$ with a positive correlation. Inflation has a negative correlation which means that higher inflation, lower NPAs and Interest rates have a direct relationship with NPAs. The bank size of Indian Bank also has a role to play in its NPAs. It has an inverse relationship which means larger the bank, lower the NPAs. Corruption Index are significant at alpha $=0.1$. Corruption has a direct relation with NPAs for Indian Bank. The diversification of the bank and Priority Sector Lending have been proved to be insignificant to the dependent variable for this bank, therefore, their correlation does not matter in this case.

\section{Conclusion}

Non-performing assets have been eroding capital and liquidity of the banking sector in India. Public Sector Banks have been relationship which means larger the bank, lower the NPAs. The diversification of the bank has a negative correlation with the dependent variable showing that a bank that diversifies its assets can avoid the occurrence of NPAs. Priority Sector Lending and Corruption Index are insignificant to the dependent variable; hence their correlation does not matter in this case. majorly hit by defaults in loan repayments and this affects the general public who have deposited their hard-earned money in these banks.

In this paper, I have considered the 4 top Public Sector BanksPNB, Andhra Bank, Corporation Bank and Indian Bank from the period of $2010-2019$ and analyzed the impact of GDP per capita, inflation rate, interest rate on NPAs in each of the 4 PSBs. Literature on effect of macroeconomic factors has only considered GDP and Inflation but, in this paper, I've tried to determine the significance of interest rates on NPAs too.

In table 7, we can see that the Macroeconomic factors have a significant influence on NPAs in all these banks. 


\begin{tabular}{|l|l|l|l|l|l|l|l|}
\hline & GDP & Inflation & $\begin{array}{l}\text { Interest } \\
\text { Rates }\end{array}$ & Corruption & $\begin{array}{l}\text { Bank } \\
\text { Size } \\
\text { (BS) }\end{array}$ & $\begin{array}{l}\text { Diversification } \\
\text { (Div) }\end{array}$ & $\begin{array}{l}\text { Priority Sector } \\
\text { Lending (PSL) }\end{array}$ \\
\hline Punjab National Bank & $\ddot{\mathrm{u}}$ & $\ddot{\mathrm{u}}$ & $\ddot{\mathrm{u}}$ & $\ddot{\mathrm{u}}$ & $\ddot{\mathrm{u}}$ & $\ddot{\mathrm{u}}$ & $\ddot{\mathrm{u}}$ \\
\hline Andhra Bank & $\ddot{\mathrm{u}}$ & $\ddot{\mathrm{u}}$ & $\ddot{\mathrm{u}}$ & $\hat{\mathrm{u}}$ & $\ddot{\mathrm{u}}$ & $\hat{\mathrm{u}}$ & $\hat{\mathrm{u}}$ \\
\hline Corporation Bank & $\ddot{\mathrm{u}}$ & $\ddot{\mathrm{u}}$ & $\ddot{\mathrm{u}}$ & $\hat{\mathrm{u}}$ & $\ddot{\mathrm{u}}$ & $\ddot{\mathrm{u}}$ & $\hat{\mathrm{u}}$ \\
\hline Indian Bank & $\ddot{\mathrm{u}}$ & $\ddot{\mathrm{u}}$ & $\ddot{\mathrm{u}}$ & $\ddot{\mathrm{u}}$ & $\ddot{\mathrm{u}}$ & $\hat{\mathrm{u}}$ & $\hat{\mathrm{u}}$ \\
\hline
\end{tabular}

Table 7: Influence of Macroeconomic, bank factors and corruption on NPAs of 4 PSBs

Bank Factors that have been considered are bank size, diversification and priority sector lending. It can be observed that bank size has a significant influence a negative correlation on NPAs in all the 4 banks. This confirms the fact that larger the bank size, lower their NPAs are.

Diversification is an important method to reduce risk and this can be seen in both PNB and Corporation Bank where it was a significant factor with negative correlation. Any bank that diversifies its assets is less prone to have NPAs.

Priority Sector Lending by banks to a few particular sectors like agriculture and allied activities, micro and small enterprises, students for erudition and other deprived groups and underprivileged sections for overall economic development of the country. This paper was aimed at seeing if this has an effect on NPAs in these 4 PSBs. It has been seen that this is significant in only Punjab National Bank.

Corruption has been unquantifiable in the past literature, but we have tried to check if it can be a determinant of NPAs in these 4 banks. It was significant in Punjab National Bank and Indian Bank with a positive correlation meaning that higher corruption leads to little due diligence before granting loans to borrowers with a conspicuous credit score. When these loans are not repaid at maturity, they become Non-performing Assets.

The Central Bureau of Investigation has booked several bank officers for misuse of official position and corruption.

\begin{tabular}{|l|l|l|}
\hline Year & Number of cases & $\begin{array}{l}\text { Amount of Money involved } \\
\text { (In Crores) }\end{array}$ \\
\hline $\mathbf{2 0 1 0}$ & 4,669 & $1,998.94$ \\
\hline $\mathbf{2 0 1 1}$ & 4,534 & $3,815.76$ \\
\hline $\mathbf{2 0 1 2}$ & 4,093 & $4,501.15$ \\
\hline $\mathbf{2 0 1 3}$ & 4,235 & $8,590.86$ \\
\hline $\mathbf{2 0 1 4}$ & 4,306 & $10,170.81$ \\
\hline $\mathbf{2 0 1 5}$ & 4,639 & $19,455.07$ \\
\hline $\mathbf{2 0 1 6}$ & 4,693 & $18,698.82$ \\
\hline $\mathbf{2 0 1 7}$ & 5,076 & $23,933.85$ \\
\hline $\mathbf{2 0 1 8}$ & 5,916 & $41,167.03$ \\
\hline $\mathbf{2 0 1 9}$ & 6,801 & $71,542.93$ \\
\hline
\end{tabular}

Table 8: Cases of bank fraud reported to RBI in the past 10 years

Source: Economic Times

There have been a number of high-profile corruption cases in both the public and private banking sector. Examples of such cases include ICICI bank's Chanda Kochhar, Yes Bank's Rana Kapoor, DHFL's Kapil Wadhawan and the involvement of Nirav Modi in the Punjab National Bank Scam. 
This paper has just considered top 4 public sector banks for the study. Further research can be done to see the effect of these factors on NPAs in all Scheduled commercial banks including private and foreign banks with additional factors like unemployment, household spending, bank management quality etc.

\section{References}

[1]. Indian Banking Sector: Current Status and the Way Forward* by Shaktikanta Das https://rbidocs.rbi.org.in/rdocs/Bulletin/PDFs/04SP 11062019FE23777F8F184903B5BE2CA4A3B057 96.PDF

[2]. Report on Trend and Progress of Banking in India 2018-19:

https://rbidocs.rbi.org.in/rdocs/Publications/PDFs/0 4CHPT4_24122019692C56B9A4DD47BCA331D2 284E7639C6.PDF

[3]. Operations and Performance of Commercial Banks: https://m.rbi.org.in/Scripts/PublicationsView.aspx?i $\mathrm{d}=19365$

[4]. RBI's Financial Stability Report: https://www.rbi.org.in/Scripts/BS_PressReleaseDis play.aspx ?prid $=48982$

[5]. World Bank: India Real GDP per capita https://data.worldbank.org/indicator/NY.GDP.PCA P.CD?locations $=$ IN

[6]. World Bank: India Inflation Rates https://data.worldbank.org/indicator/NY.GDP.DEF L.KD.ZG?locations $=\mathrm{IN}$

[7]. World Bank: Real Interest Rates https://data.worldbank.org/indicator/FR.INR.RINR? locations $=\mathrm{IN}$

[8]. PNB: Annual Reports https://www.pnbindia.in/annual-reports.html

[9]. Andhra Bank: Annual Reports https://www.andhrabank.in/english/AnnualReport.a $\operatorname{spx}$

[10]. Corporation Bank: Annual Reports https://corpbank.com/node/62171

[11]. Indian Bank: Annual Reports https://www.indianbank.in/departments/financialresults-ib/

[12]. Transparency International: Corruption Perception Index https://www.transparency.org/en/cpi

[13]. Louzis, Vouldis, and Metaxas. (2012). Macroeconomic and bank-specific determinants of nonperforming loans in Greece: A comparative study of mortgage, business and consumer

[14]. loan portfolios. Journal of Banking \& Finance, 36, 1012-1027.
[15]. Kaur, S., \& Sharma, D. (2011). Performance Appraisal of Public Sector Banks in India- Top 10 PSBs in 2010.

[16]. Park, J. (2012). Corruption, soundness of the banking sector, and economic growth: A cross country study.

[17]. Laila, M. (2017). MACROECONOMIC AND BANK SPECIFIC DETERMINANTS OF NONPERFORMING LOANS (NPLS) IN THE INDIAN BANKING SECTOR.

[18]. Bank fraud touches unprecedented Rs 71,500 crore in 2018-19:

RBI https://economictimes.indiatimes.com/news/econo my/finance/bank-fraud-touches-unprecedented-rs71500-crore-in-2018-19rbi/articleshow/69631871.cms?from $=\mathrm{mdr}$

\section{Appendix}

\section{List of Tables}

\begin{tabular}{|c|c|}
\hline Table No. & Title \\
\hline 1 & Net NPAs to Net Advances for 4 PSBs. \\
\hline 2 & Data Variables and their definition \\
\hline 3 & Regression results for Punjab National Bank \\
\hline 4 & Regression results for Andhra Bank \\
\hline 5 & Regression results for Corporation Bank \\
\hline 6 & Regression results for Indian Bank \\
\hline 7 & $\begin{array}{l}\text { Influence of Macroeconomic, bank factors and } \\
\text { corruption on NPAs of } 4 \text { PSBs }\end{array}$ \\
\hline 8 & $\begin{array}{l}\text { Cases of bank fraud reported to RBI in the past } \\
10 \text { years }\end{array}$ \\
\hline
\end{tabular}

